INTERNATIONAL JOURNAL OF MULTidisciplinARY RESEARCH AND ANALYSis

ISSN(print): 2643-9840, ISSN(online): 2643-9875

Volume 04 Issue 09 September 2021

DOI: 10.47191/ijmra/v4-i9-20, Impact Factor: 6.072

Page No.- 1334-1341

\title{
Awareness and Behavior to Prevent Coronavirus Pandemic: A Case Study of Young People in Southern Of Viet Nam
}

\author{
Nguyen Thanh Hung ${ }^{1}$, Nguyen Thi Cam Phuong ${ }^{2}$, Ho My Dung ${ }^{3}$ \\ ${ }_{1,2,3}$ Tra Vinh University, Tra Vinh University, Vietnam.
}

\begin{abstract}
The study was conducted to explore public awareness and behaviors in response to the COVID-19 pandemic through a survey of 302 young people in the southern provinces of Vietnam. The Confirmatory Factor Analysis (CFA) and Structural Equation Modeling (SEM) were applied to validate relationships between elements of the modeling. The research shown that knowledge of pandemic, awareness of the benefits of preventive measures, and trust in the Government's effort in disease prevention had a positive impact on preventive behavior against COVID-19. It takes proportional effect on proactive behavior in purchasing daily goods and medical products.
\end{abstract}

KEYWORDS- COVID-19, awareness of COVID-19, preventive behavior

\section{INTRODUCTION}

The pandemic of respiratory infections caused by a new type of the corona virus (COVID-19) has had devastating global consequences. In December 2019, several cases of unexplained pneumonia were reported in Wuhan, the capital of Hubei province in central China. Pneumonia was subsequently diagnosed as due to a new type of coronavirus and was named COVID19 by the World Health Organization (Wu et al., 2020). Since then, the COVID-19 epidemic has spread beyond Hubei province, especially from Wuhan city and spread across mainland China. Subsequently, COVID-19 also spread outside China and affected many countries around the world.

According to statistics of the Ministry of Health, as of August 21, 2020, there were 22,860,184 COVID-19 cases, of which 797,104 deaths. In Vietnam, there are 1,007 infections, 25 deaths. Although, a country with a population of about 96.2 million people, the most worrying thing is that Vietnam has a border with China, where the first disease outbreak in the world at the end of 2019. Currently, production, business, trade and education activities are seriously affected, students often have to drop out of school because of the pandemic outbreak ... The Government of Vietnam has been actively adopting a variety of measures to control COVID-19, including providing medical treatment, monitoring disease progression and even controlling movement of residents within and between cities. However, the control and prevention of the epidemic from spreading to the community are also facing many difficulties, related to awareness and attitudes of community towards epidemic prevention. This article discusses the effects of awareness and behavior to prevent the COVID-19 epidemic in the community - a case study of young people in the Southern Vietnam, so as to assess the youth's awareness of the covid-19 pandemic, analyze the youth's behavior in preventing the epidemic and discuss measures to prevent the COVID-19 epidemic in order to minimize its negative effects.

\section{APPROACH AND METHODOLOGY}

COVID-19 stands for Coronavirus disease 2019, an infectious pandemic caused by the SARS-CoV-2 virus - a new type of the Corona virus, which causes acute respiratory infections in humans and is likely to spread from person to person. There have been many previous studies on corona virus strains, articles on awareness, attitude and practice related to coronavirus by the public in Saudi Arabia (Almutairi, Khalid M. et al., 2015) that personal knowledge and being able to predict human behavior are of great importance when assessing the very high level of clinical preparedness for pandemics. Another study argues that preventive behavior against emerging infectious diseases such as MERS-CoV is influenced by risk perception (Jeong - Sil Choi, JiSoo Kim, 2016). Besides, Yang \& Chu (2018) showed that awareness of virus risk is related to the emotional and behavioral level before Ebola outbreak in the US public. In addition, according to previous studies, the preventive behavior of college students 


\section{Awareness and Behavior to Prevent Coronavirus Pandemic: A Case Study of Young People in Southern Of Viet Nam}

against respiratory infections such as SARS and H1N1 is influenced by their level of knowledge (Choi and Yang, 2010); and risk perception ((Brug et al., 2004) (Hussain, Hussain, \& Hussain, 2012).

Recent researches on the knowledge of the Chinese community proved the importance of cognitive level, ability to control COVID-19 and their relationship to emotional and behavioral responses, social participation and preventive behavior (Kai Dou, Jian-Bin Li, 2019). The outbreak of COVID-19 has caused great tension in the community in China. This study has examined the factors of knowledge, perception of severity and the ability to control COVID-19, evaluating perceptions of the three factors above as a core process to deal with stress in solving like the feelings and behavior of the community.

The Theory of Planned Behavior -- TPB (Ajzen, 1991), developed from Theory of Reasoned Action - TRA (Ajzen \& Fishbein, 1975), assuming that a behavior can be predicted via behavioral tendencies to perform that behavior. The behavioral tendency is the degree of effort people make the action (Ajzen, 1991). First, attitudes are conceptualized as positive or negative assessments of the performance behavior. The second factor is the social influence which refers to the perceived social pressure to perform or not perform the action. Finally, the Theory of Planned Behavior was developed by Ajzen by adding a control element of perceptual behavior to the TRA model. In this research context, the structural components of the TPB include Knowledge, awareness of severity, awareness of risks, and awareness of benefits affecting the youth's COVID-19 pandemic prevention behavior.

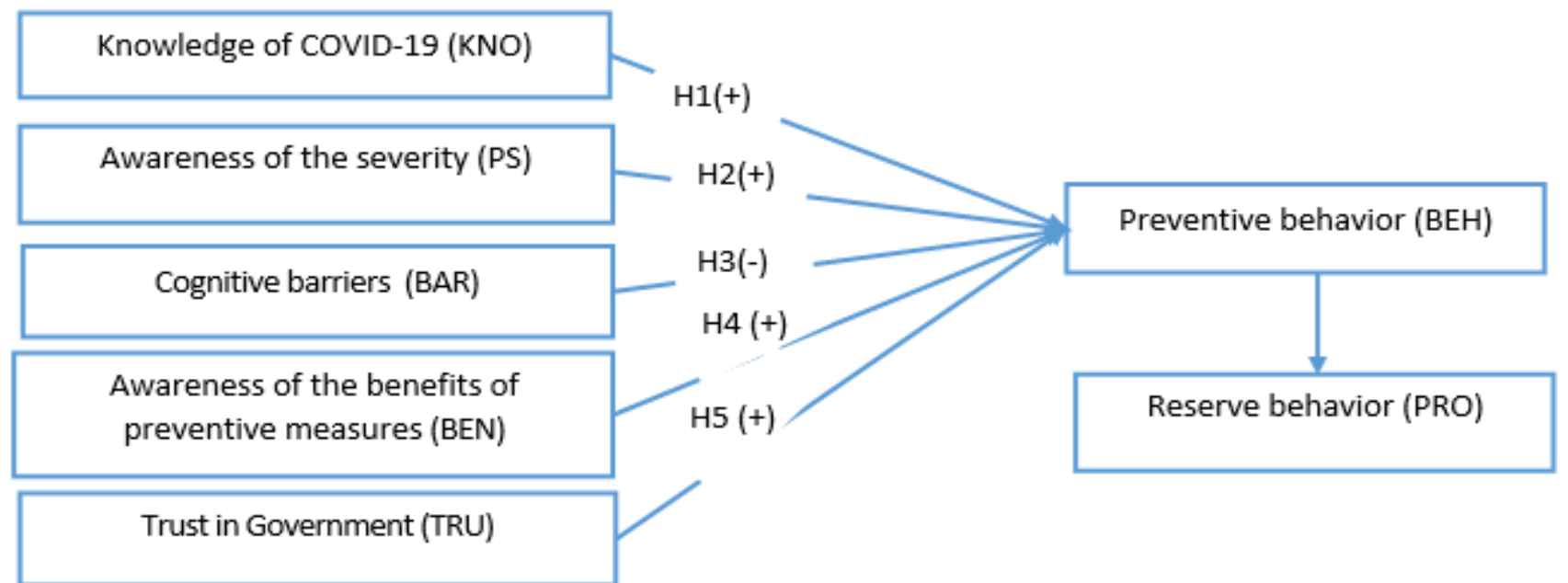

Figure 1: Proposed research model

Research hypothesis:

H1: The more knowledge of Covid's knowledge, the higher the disease prevention behavior will be

$\mathrm{H} 2$ : Awareness of the increasing severity of epidemics will increase preventive behavior

H3: Cognitive barriers have an inverse effect with preventive behavior

H4: Perception of benefits about preventive measures positively affects preventive behavior

H5: Trust in the Government's anti-epidemic efforts has even more positively influenced disease prevention behavior

H6: Awareness of epidemic prevention affects proportionally with preventive behavior

\section{RESEARCH METHODS}

With a convenient sampling method and respondents are young people in the south of Vietnam. The study was conducted in two period:

The preliminary research: applied qualitative analysis to explore the influence factors and prevention behavior of young people in the southern region about COVID-19. Desk research methods were performed on published sources of information, documents and data. The expert discussions were also conducted with semi-structured questions to develop and complete the scale in the research model (Table 1). Then, the scale is transformed into a preliminary survey questionnaire with a 5 -level Likert scale. The author surveyed with a sample size of 100 to test respondents 'understanding of statements, detecting errors in questionnaire design. Using Cronbach's Alpha test to remove the coefficients' scales that have Alpha $<0.6$ and the total variable correlation is lower than 0.3 (Nguyen Dinh Tho, 2011). According to Hair et al. (1998), the minimum sample size is $n=5 X$ (with $X$ : number of observed variables). In this study, there are all 34 observed variables so the requirement of minimum sample size is 170. In order to increase representation of the sampling, this study implemented analysis with 302 observations. 
Awareness and Behavior to Prevent Coronavirus Pandemic: A Case Study of Young People in Southern Of Viet Nam

The scales in research concepts are based on the scales of Kai Dou and Jian-Bin Li (2019), the study of Alsulaiman (2018), combined with the Ministry of Health's instruction on preventive measures against COVID-19 in Vietnam in 2020.

Table 1: Summary of scales and tests Cronbach's Alpha

\begin{tabular}{|c|c|c|c|c|c|}
\hline No & \multicolumn{2}{|c|}{ Variable } & $\begin{array}{l}\text { Cronbach's } \\
\text { Alpha }\end{array}$ & $\begin{array}{l}\text { Corrected } \\
\text { Item-Total } \\
\text { Correlation }\end{array}$ & $\begin{array}{l}\text { Cronbach's } \\
\text { Alpha if Item } \\
\text { Deleted }\end{array}$ \\
\hline \multicolumn{6}{|c|}{ I. Knowledge of COVID-19 - KNO } \\
\hline & KN1 & Understanding COVID-9 & \multirow{6}{*}{.918} & .797 & .900 \\
\hline & KN2 & Know the source & & .739 & .909 \\
\hline & KN3 & Understand the mechanism of transmission & & .841 & .893 \\
\hline & KN4 & Identify the symptoms & & .751 & .906 \\
\hline & KN5 & Understand how to prevent disease & & .777 & .903 \\
\hline$€$ & KN6 & $\begin{array}{l}\text { Regularly access and update information about } \\
\text { COVID-19 }\end{array}$ & & .719 & .910 \\
\hline \multicolumn{6}{|c|}{ II. Perception of the severity (PS) } \\
\hline & PS1 & $\begin{array}{l}\text { I get scared when I think about coronavirus } \\
\text { infection }\end{array}$ & \multirow{5}{*}{0.789} & .477 & .777 \\
\hline$\oint$ & PS2 & $\begin{array}{l}\text { My heart beats fast when I think about } \\
\text { coronavirus }\end{array}$ & & .669 & .715 \\
\hline & PS3 & I will die if I get coronavirus & & .674 & .714 \\
\hline 1 & PS4 & $\begin{array}{l}\text { I feel great anxiety about quarantine when } \\
\text { coronavirus infection is suspected }\end{array}$ & & .579 & .748 \\
\hline 1 & PS5 & $\begin{array}{l}\text { If I have a coronavirus infection, other members } \\
\text { of my home will get sick }\end{array}$ & & .451 & .785 \\
\hline \multicolumn{6}{|c|}{ III. Cognitive barriers (BAR) } \\
\hline 1 & BAR1 & $\begin{array}{l}\text { Hand wash and/or antibacterial solutions are not } \\
\text { available where I spend most of the day }\end{array}$ & \multirow{6}{*}{0.832} & .544 & .818 \\
\hline 1 & BAR2 & $\begin{array}{l}\text { Washing your hands often with soap and water is } \\
\text { not convenient }\end{array}$ & & .657 & .794 \\
\hline 1. & BAR3 & It's hard to avoid close contact with sick people & & .495 & .826 \\
\hline 1 & BAR4 & $\begin{array}{l}\text { Preventive measures related to coronavirus are } \\
\text { difficult to apply in everyday situations }\end{array}$ & & .674 & .791 \\
\hline 1 & BAR5 & $\begin{array}{l}\text { Washing your hands often with soap and water } \\
\text { or antibacterial costs a lot of money }\end{array}$ & & .709 & .784 \\
\hline 1 & BAR6 & $\begin{array}{l}\text { Uncomfortable wearing a mask to prevent } \\
\text { coronavirus infection }\end{array}$ & & .554 & .816 \\
\hline \multicolumn{6}{|c|}{ IV. Benefits of preventive measures (BEN) } \\
\hline 1 & BEN1 & $\begin{array}{l}\text { If I wash my hands frequently with soap and } \\
\text { water, I will not be infected coronavirus }\end{array}$ & \multirow{3}{*}{.840} & .591 & .903 \\
\hline 1 & BEN2 & $\begin{array}{l}\text { I cover my mouth and nose by tissues when } \\
\text { coughing and sneezing as they are healthy } \\
\text { behaviors }\end{array}$ & & .796 & .688 \\
\hline 2 & BEN3 & $\begin{array}{l}\text { If I follow Ministry of Health's recommendations } \\
\text { on coronavirus, risk of infection will be reduced }\end{array}$ & & .750 & .740 \\
\hline \multicolumn{6}{|c|}{ V. Trust in the Government (TRU) } \\
\hline 2 & TRU2 & $\begin{array}{l}\text { The government should quarantine patients in } \\
\text { special hospitals }\end{array}$ & & .553 & .636 \\
\hline 2 & TRU3 & The government must be willing to allow schools & & .511 & .665 \\
\hline
\end{tabular}


Awareness and Behavior to Prevent Coronavirus Pandemic: A Case Study of Young People in Southern Of Viet Nam

\begin{tabular}{|c|c|c|c|c|c|}
\hline No & \multicolumn{2}{|c|}{ Variable } & \multirow[t]{3}{*}{$\begin{array}{l}\text { Cronbach's } \\
\text { Alpha }\end{array}$} & \multirow[t]{2}{*}{$\begin{array}{l}\text { Corrected } \\
\text { Item-Total } \\
\text { Correlation }\end{array}$} & \multirow[t]{2}{*}{$\begin{array}{l}\text { Cronbach's } \\
\text { Alpha if Item } \\
\text { Deleted }\end{array}$} \\
\hline & & $\begin{array}{l}\text { to drop out of school if the number of infections } \\
\text { increases }\end{array}$ & & & \\
\hline 2 & TRU4 & $\begin{array}{l}\text { If I follow the health department's coronavirus } \\
\text { recommendations, I will help reduce the spread } \\
\text { of coronavirus. }\end{array}$ & & .530 & .653 \\
\hline \multicolumn{6}{|c|}{ VI. Proactive behavior (BEH) } \\
\hline 2 & BEH1 & Limit participation in activities in public places & \multirow{7}{*}{.922} & .752 & .910 \\
\hline 2 & $\mathrm{BEH} 2$ & $\begin{array}{l}\text { Avoid contact with people who have a cough or } \\
\text { fever }\end{array}$ & & .828 & .904 \\
\hline 2 & BEH3 & $\begin{array}{l}\text { Cover your nose and mouth with a tissue when } \\
\text { you cough or sneeze }\end{array}$ & & .710 & .915 \\
\hline 2 & $\mathrm{BEH} 4$ & $\begin{array}{l}\text { Use a mask to cover your nose and mouth in } \\
\text { crowded places }\end{array}$ & & .800 & .906 \\
\hline 2 & BEH5 & $\begin{array}{l}\text { Throw away the tissue or mask in the trash after } \\
\text { you use it }\end{array}$ & & .652 & .923 \\
\hline 2 & BEH6 & $\begin{array}{l}\text { If I experience flu symptoms, I avoid normal } \\
\text { activities such as commuting, traveling, shopping }\end{array}$ & & .836 & .903 \\
\hline 3 & BEH7 & $\begin{array}{l}\text { Observe coronavirus precautions according to } \\
\text { the health department's instructions in everyday } \\
\text { life }\end{array}$ & & .768 & .909 \\
\hline \multicolumn{6}{|c|}{ VII. Reserve behavior (PRO) } \\
\hline 3 & PRO1 & $\begin{array}{l}\text { Stockpiling shopping, focusing on dry foods such } \\
\text { as instant noodles and canned food }\end{array}$ & \multirow{3}{*}{.663} & .513 & .548 \\
\hline 3 & PRO2 & $\begin{array}{l}\text { Procurement of hygiene, personal care and home } \\
\text { care products including soap, , household } \\
\text { cleaning product, paper towels }\end{array}$ & & .531 & .518 \\
\hline 3 & PRO3 & $\begin{array}{l}\text { Storage of antibacterial products, hand sanitizer, } \\
\text { antiseptic water, mask }\end{array}$ & & .422 & .669 \\
\hline
\end{tabular}

The official research is focused on using quantitative research methods, the official questionnaire is used to survey in terms of knowledge, perception, and behavior to prevent disease COVID - 19 of the community in the Southern region to collect primary data for quantitative analysis.

\section{RESEARCH RESULTS AND DISCUSSIONS}

\subsection{Descriptive statistics of the survey sample}

There are $32 \%$ of male, $68 \%$ of female out of the 302 observations. In term of age, $80 \%$ of young people are from $18-25$ years old, $20 \%$ are between 26 and 35 years old.

Education level: the number of employees with high school or lower degree accounts for about $39 \%, 52 \%$ has a college or university degree and $9 \%$ has post-graduate degree.

Career: $84 \%$ of surveyees are young students; $7 \%$ are employees in enterprises; $5 \%$ are teachers and $4 \%$ are working in local departments.

Living place: surveyees living in rural areas account for 55\%; $39 \%$ are living in urban areas; the remaining $6 \%$ are living in the suburbs of the city. 
Awareness and Behavior to Prevent Coronavirus Pandemic: A Case Study of Young People in Southern Of Viet Nam

Table 2. Dispersion of measuring scale

\begin{tabular}{|l|l|l|l|l|l|l|l|}
\hline & KN & PS & TRU & BAR & BEN & BEH & PRO \\
\hline Mean & 3.95 & 3.15 & 4.48 & 2.84 & 4.04 & 4.65 & 3.98 \\
\hline Std. Deviation & 0.77 & 0.93 & 0.59 & 0.99 & 0.68 & 0.56 & 0.73 \\
\hline Variance & 0.60 & 0.86 & 0.35 & 0.98 & 0.46 & 0.31 & 0.53 \\
\hline
\end{tabular}

Analyzing the distribution and scatter of the research concepts, we find out that deviations from the mean of the variables are relatively low (standard deviation only fluctuates from 0.56 to 0.99 ). It measn that the distribution of these variables does not deviate far from the mean.
I. Knowledge of COVID-19 - KNO
II. Perception of the severity (PS)
III. Cognitive barriers (BAR)
IV. Benefits of preventive measures (BEN)
V. Trust in the Government (TRU)
VI. Preventive behavior (BEH)
VII. Proactive behavior (PRO)

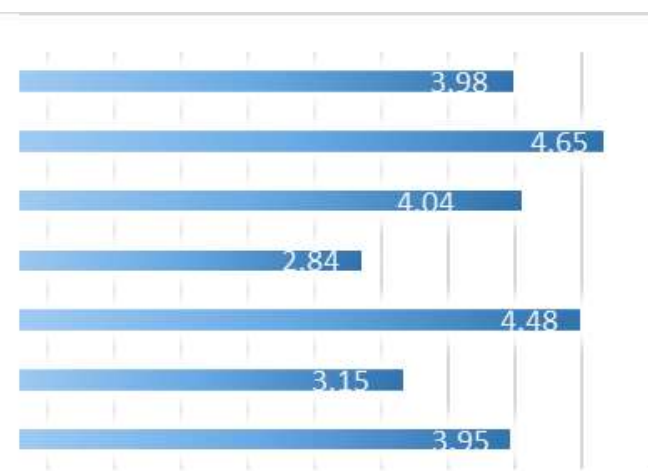

0.000 .501 .001 .502 .002 .503 .003 .504 .004 .505 .00

Figure 1: Statistics on the level of awareness and behavior to prevent COVID-19

The figure shows that the young people surveyed had high belief in the Government's anti-epidemic power in the country (4.48). Because of the belief together with the formula in the application of preventive measures, and relatively low cognitive barriers (2.84), the youth's epidemic prevention behavior in the Southern Vietnam is at a very high level (4.65). Besides, it can be a reason.

\subsection{Confirmatory Factors Analysis (CFA)}

CFA analysis results of the critical model have $\mathrm{p}=0.000<0.05 ; \chi^{2}$ (Chi-square) $=862.469 \mathrm{df}=472 ; \mathrm{CMIN} / \mathrm{df}=1.827<3($ Carmines \& Mclver, 1981); $\mathrm{CFI}=0.926>0.9 ; \mathrm{TLI}=0.918>0.9$ is approximately $0.9 ; \mathrm{RMSEA}=0.052<0.08$. The indicators satisfy the requirements to conclude the model is consistent with the market data.

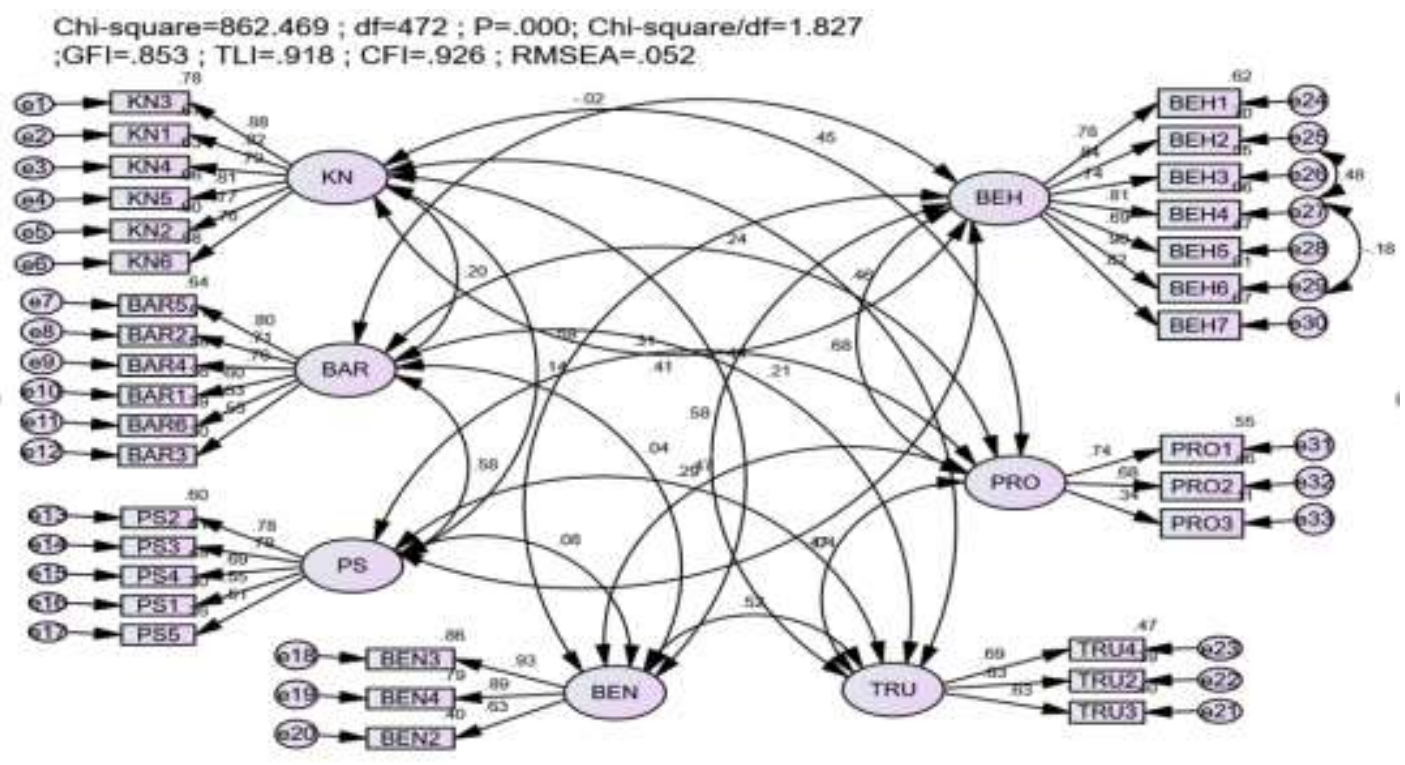

Figure 2: Results of testing the critical model

(Source: Results of processing survey data in 2019) 


\section{Awareness and Behavior to Prevent Coronavirus Pandemic: A Case Study of Young People in Southern Of Viet Nam}

\subsection{General evaluation of composite reliability and Convergent validity}

The results of the test of the composite reliability coefficient (CR) ranging from 0.660 to 0.937 , meeting the requirement $\geq 0.60$ so the scale of factors ensures reliability. CFA analysis results show that standardized loading Estimates from 0.521 to 0.925 are $\geq 0.5$; therefore, it can be concluded that the observed variables used to measure the factors and components in the research model reach convergent validity.

\subsection{The results of the suitability test of the research model}

SEM model test results show that the model has $P=0.000<0.001 ; \chi 2$ (Chi-square) $=812.702 ; \mathrm{df}=504 ; \mathrm{CMIN} / \mathrm{df}=1.00<3$ (Carmines \& Mclver, 1981); $\mathrm{CFI}=0.936>0.9 ; \mathrm{TLI}=0.929>0.9 ; \mathrm{GFI}=0.861$ approximately 0.9; $\mathrm{RMSEA}=0.049<0.08$. The indicators satisfy the requirements to conclude the model is consistent with the market data. Through the estimation results from the model, all variables are statistically significant at the $5 \%$ level.

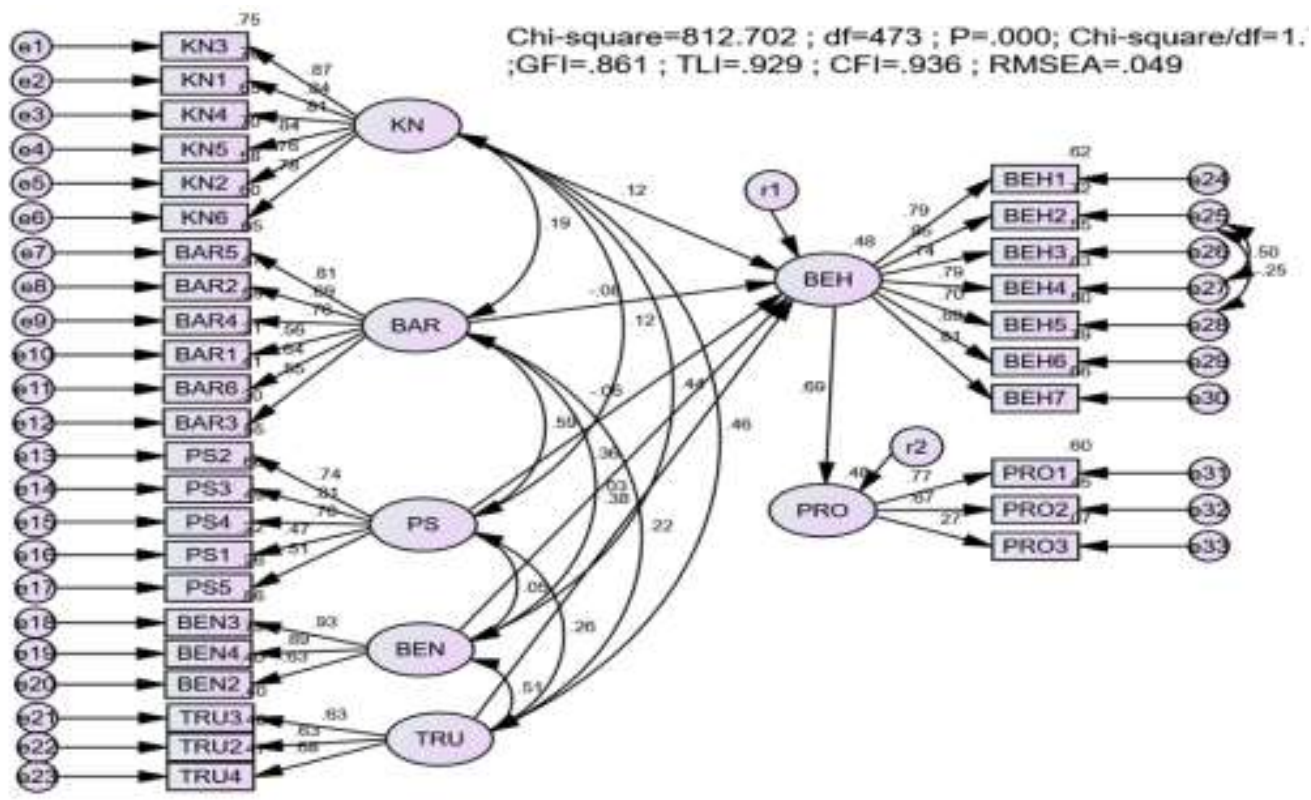

Figure 3: Results of testing the research hypothesis

(Source: Results of processing survey data in 2019)

\subsection{Test research hypothesis}

Based on the Estimate table, the author statistic the necessary information for testing hypothesis in Table 3 as follows:

Table 3: Research hypothesis testing results

\begin{tabular}{|l|l|l|l|l|l|l|l|l|}
\hline H & \multicolumn{2}{|l|}{ Variable } & Standardized Estimate & S.E & CR & P & Results \\
\hline H1 & BEH & $<---$ & KN & .119 & .042 & 1.957 & .050 & Accepted \\
\hline H2 & BEH & $<---$ & BAR & -.084 & .036 & -1.184 & .236 & Rejected \\
\hline H3 & BEH & $<---$ & PS & -.060 & .042 & -.832 & .405 & Rejected \\
\hline H4 & BEH & $<---$ & BEN & .358 & .050 & 5.155 & $* * *$ & Accepted \\
\hline H5 & BEH & $<---$ & TRU & .378 & .087 & 4.211 & $* * *$ & Accepted \\
\hline H6 & PRO & $<---$ & BEH & .694 & .090 & 8.982 & $* * *$ & Accepted \\
\hline
\end{tabular}

Note: $* * *=0.001$

(Source: Results of processing survey data)

The results of a standardized estimate of the relationship between concepts to disease prevention behavior (BEH) and preventive behavior (PRO) reveal the factors "Government confidence in efforts to fight disease - TRU ", Advantages of disease prevention measures - BEN", and "Knowledge about the Covid epidemic - 19 "of the youth in the southern region all have a positive effect on disease prevention behavior. And the statistically significant $\beta$-weights are $0.378,0.358$ and 0.119 , respectively. The higher the epidemic prevention behavior increases the preventive behavior of purchasing essential goods and medical goods (hand sanitizer, face mask ...), which are completely relevant and have statistical significance at the level. $1 \%$ with the coefficient $\beta$ corresponding to 0.694 . 


\section{Awareness and Behavior to Prevent Coronavirus Pandemic: A Case Study of Young People in Southern Of Viet Nam}

Although there is an inverse correlation between "Barrier Cognitive Barrier - BAR" and "Perception of the severity of disease PS" and disease prevention behavior, the relationship is not significant. Statistic at $5 \%$ with the current sample.

\section{CONCLUSION}

In order to effectively control and limit COVID-19 epidemics in the community, the implementation of preventive measures is necessary. However, factors of awareness and attitudes towards preventive behavior are important factors in avoiding the spread of the epidemic into the community. Research results have shown that, in addition to disease knowledge and awareness of the advantages of preventive measures, there is an influence on disease prevention behavior as previous studies (Almutairi, Khalid M. et al. ,, 2015); (Choi and Yang, 2010); (Hussain et al., 2012), the government's confidence in the anti-epidemic effort plays a very important role in Vietnam. Therefore, in order to raise awareness and behavior to prevent COVID epidemics in the community, it is necessary to take measures such as

Firstly, Awareness raising among the community, especially young people, is due to the increasing rate of COVID epidemics among people aged 20-40 (WHO, 2020). Therefore, measures to prevent COVID epidemics need to be widely propagated on the media (newspaper, television, social networks,).

Secondly, it is necessary to increase community knowledge about covid disease, its severity, symptoms of infection, and causes of transmission and measures to prevent the current state of infection to the community.

Thirdly, the effectiveness of the application of measures to prevent epidemics issued by the Ministry of Health needs to be listed and widely disseminated for people to implement, typically wearing masks when going out etc.

Finally, it is important to improve community confidence in the Government's anti-epidemic efforts through the implementation of regulations during the epidemic such as: suspension of business activities, schools, social isolation, and restriction of events. ...., although this has a significant impact on production and business activities, but it has a positive effect in preventing epidemics from spreading on a large scale.

\section{REFERENCE}

1) Ajzen, I. (1991). The theory of planned behavior. Orgnizational Behavior and Human Decision Processes, 50, $179-211$. https://doi.org/10.1016/0749-5978(91)90020-T

2) Almutairi, Khalid M. et al.,. (2015). Awareness, Attitudes, and Practices Related to Coronavirus Pandemic Among Public in Saudi Arabia. Family \& Community Health.

3) Alsulaiman, S. A. (2018). Health crisis in the kingdom of Saudi Arabia: A study of Saudis' knowledge of coronavirus, attitudes toward the ministry of health's coronavirus preventive campaigns, and trust in coronavirus messages in the media. Dissertation Abstracts International Section A: Humanities and Social Sciences, 79(10-A(E)). Retrieved from https://search.ebscohost.com/login.aspx?direct=true\&db=psyh\&AN=2018-34219-250\&amp\%0Alang=nl\&site=ehostlive

4) Brug, J., Aro, A. R., Oenema, A., De Zwart, O., Richardus, J. H., \& Bishop, G. D. (2004). SARS risk perception, knowledge, precautions, and information sources, the Netherlands. Emerging Infectious Diseases, 10(8), 1486-1489. https://doi.org/10.3201/eid1008.040283

5) Choi, Jeong Sil · Yang, N. (2010). Perceived Knowledge, Attitude, and Compliance with Preventive Behavior on Influenza A (H1N1) by University Students. 22(3), 250-259.

6) Fishbein, M., \& Ajzen, I. (1975). Belief, attitude, intention, and behavior Reading. MA: Addison-Wesley, $913-927$.

7) Hassan, H. M. (2016). Knowledge, Attitude, and Belief of Al-Ghad College Students Toward Coronavirus Infection, Riyadh, Saudi Arabia. International Journal of Preventive and Public Health Science.

8) Hussain, Z. A., Hussain, S. A., \& Hussain, F. A. (2012). Medical students' knowledge, perceptions, and behavioral intentions towards the H1N1 influenza, swine flu, in Pakistan: A brief report. American Journal of Infection Control, 40(3), e11-e13. https://doi.org/10.1016/j.ajic.2011.12.004

9) Jeong - Sil Choi, Ji-Soo Kim. (2016). Factors influencing preventive behavior against Middle East Respiratory SyndromeCoronavirus among nursing students in South Korea. Elsevier.

10) Kai Dou, Jian-Bin Li, A. Y. (2019). Acknowledgement of Financial Support. Caries Research, 53(6), 682-682. https://doi.org/10.1159/000503316

11) Yang, J. Z., \& Chu, H. (2018). Who is afraid of the Ebola outbreak? The influence of discrete emotions on risk perception. Journal of Risk Research, 21(7), 834-853. https://doi.org/10.1080/13669877.2016.1247378 
Awareness and Behavior to Prevent Coronavirus Pandemic: A Case Study of Young People in Southern Of Viet Nam

12) Ministry of Health. (2020). 9 latest measures to prevent COVID-19 epidemic people need to know. https://ncov.moh.gov.vn/-/9-bien-phap-moi-nhat-phong-chong-dich-covid-19-nguoi-dan-can-biet.

13) Ministry of Health. (2020). WHO warns about the rate of COVID-19 spread from people aged 20-40.https: //ncov.moh.gov.vn/-/who-canh-bao-ve-toc-o-lay-lan -dich-covid-19-year-old-in-o-year-old-20-40 